Article

\title{
Evaluation of Calcium Alginate-Based Biopolymers as Potential Component of Membranes for Recovering Biosurfactants from Corn Steep Water
}

\author{
Andrea Martínez-Arcos ${ }^{1}$, Mònica Reig ${ }^{2}{ }^{\mathbb{D}}$, José Manuel Cruz ${ }^{1} \mathbb{D}$, José Luis Cortina ${ }^{2,3} \mathbf{D}^{\mathbb{D}}$, Ana Belén Moldes ${ }^{1} \mathbb{D}$ \\ and Xanel Vecino ${ }^{1, *(1)}$ \\ 1 Chemical Engineering Department, Campus As Lagoas-Marcosende, School of Industrial \\ Engineering-CINTECX, University of Vigo, 36310 Vigo, Spain; andrea.martinez.arcos@uvigo.es (A.M.-A.); \\ jmcruz@uvigo.es (J.M.C.); amoldes@uvigo.es (A.B.M.) \\ 2 Barcelona Research Center for Multiscale Science and Engineering, Chemical Engineering Department, \\ Campus Diagonal-Besòs, Escola d'Enginyeria de Barcelona Est, Universitat Politècnica de Catalunya, \\ 08930 Barcelona, Spain; monica.reig@upc.edu (M.R.); jose.luis.cortina@upc.edu (J.L.C.) \\ 3 CETaqua, Carretera d'Esplugues 75, 08940 Cornellà de Llobregat, Spain \\ * Correspondence: xanel.vecino@uvigo.es; Tel.: +34-986-130-190
}

check for

updates

Citation: Martínez-Arcos, A.; Reig, M.; Cruz, J.M.; Cortina, J.L.; Moldes, A.B.; Vecino, X. Evaluation of Calcium Alginate-Based Biopolymers as Potential Component of Membranes for Recovering Biosurfactants from Corn Steep Water. Water 2021, 13, 2396. https://doi.org/10.3390/ w13172396

Academic Editor: Antonio Zuorro

Received: 10 August 2021

Accepted: 30 August 2021

Published: 31 August 2021

Publisher's Note: MDPI stays neutral with regard to jurisdictional claims in published maps and institutional affiliations.

Copyright: (c) 2021 by the authors. Licensee MDPI, Basel, Switzerland. This article is an open access article distributed under the terms and conditions of the Creative Commons Attribution (CC BY) license (https:// creativecommons.org/licenses/by/ $4.0 /)$.

\begin{abstract}
Corn steep water (CSW) is a complex agro-food stream that is used as a source of costcompetitive biosurfactants, since they are produced spontaneously in the steeping process of corn, avoiding production costs. Nevertheless, the extraction of biosurfactants from CSW using sustainable processes is still a challenge. Consequently, the use of calcium alginate membranes could present a novel and sustainable technology for recovering biosurfactants from aqueous streams. Therefore, the aim of this work is to evaluate calcium alginate-based biopolymers, without and with the presence of grape marc as an additive, as a key component of membranes for the recovery of biosurfactants in corn steep water. Biosurfactants are present in CSW, together with other inorganic solutes and biomolecules, such as organic acids, sugars, cations, anions as well as metals. Hence, the competition of these mentioned compounds for the active sites of the calcium alginate-based biopolymers was high. However, they showed a good adsorption capacity for biosurfactants, recovering around $55 \pm 2 \%$ and $47 \pm 1 \%$, of biosurfactants from CSW using both calcium alginatebased biopolymers, with and without biodegraded grape marc. Regarding adsorption capacity, it was $54.8 \pm 0.6 \mathrm{mg}$ biosurfactant/g bioadsorbent for the biopolymer containing grape marc, and $46.8 \pm 0.4 \mathrm{mg}$ biosurfactant/g bioadsorbent for the calcium alginate-based biopolymer alone. Based on these results, it could be postulated that the formulation of green membranes, based on calcium alginate-based polymers, could be an interesting alternative for the recovery of biosurfactants from aqueous streams including CSW.
\end{abstract}

Keywords: corn stream; surface-active compounds; eco-adsorbents; green membranes; resource recovery

\section{Introduction}

Corn steep water (CSW) is a fermented stream obtained as a by-product in the wetmilling corn industry, when the corn is steeping under acid conditions $(\mathrm{pH}=4)$, high temperatures $\left(45-52^{\circ} \mathrm{C}\right.$ ) and in presence of $\mathrm{SO}_{2}(\mathrm{~g})$ and lactic acid bacteria or Bacillus [1]. CSW is commonly used in biotechnology processes as a low-cost source of nitrogen [2-4] as well as an ingredient in animal feed due to its nutritional properties $[5,6]$. However, CSW has been proposed as a direct source of biosurfactants due to the presence of lactic acid bacteria, which are producers of this type of surface-active compounds $[1,7,8]$. In fact, it has recently been isolated and identified that Aneurinibacillus aneurinilyticus is the main biosurfactant-producing Bacillus strain in CSW [9]. 
Biosurfactants are microbial surfactants produced by microorganisms that not only have similar or equal properties than their chemical homologous (e.g., reduce surface tension, emulsifying properties, solubilizing, and stabilizing agent, among others), but are also very promising and interesting substances, since they are composed of natural structures (lipids, proteins, and carbohydrates) compatible with the composition of cell membranes [10-13]. Several carbon sources as well as energy are used for microorganisms to grow. The combination of carbon sources (e.g., agro-food products or wastes) with insoluble substrates (e.g., hydrocarbons, oils) facilitates the intracellular diffusion and the biological production of diverse substances, such as biosurfactants [12]. Hence, the synthesis of biosurfactants is a growth-dependent production and frequently arises in resting microbial cell systems [13]. In addition, microorganisms can produce biosurfactants with different molecular structures and characteristics (e.g., surface activity), being a combination of a hydrophobic chain (e.g., fatty acids) with a hydrophilic moiety (e.g., carbohydrates, peptides, amino acids, alcohols, so on) [12]. Regarding their chemical composition, there are low-molecular-weight biosurfactants, like glycolipids, lipopeptides, and flavolipids, and high-molecular-weight biosurfactants, such as polysaccharides, proteins, lipopolysaccharides, lipopolysaccharides, and lipoproteins [11]. Nevertheless, the biosurfactants commercialized at the moment are produced in controlled fermentation processes, which make them non-cost competitive with chemically produced surfactants. Hence, the industrial application of biosurfactants is limited by their high production cost due to the complex recovery and purification stages [10-13]. For that reason, in a context of a circular economy, the use of streams generated in agro-food industries like CSW, where biosurfactants are produced spontaneously, it is an interesting alternative to obtain cost-competitive and value-added biosurfactants, increasing the market opportunities for these secondary raw materials.

The ionic charge, water solubility and location of the surface-active sites (e.g., intracellular, extracellular, or cell-bound) of biosurfactant molecules define the required processing stages needed for their recovery. Therefore, there are several techniques that can be applied for the selective separation and recovery of biosurfactants such as acid precipitation (e.g., acidic solutions, ammonium sulfate solutions and in non-aqueous media), crystallization, chromatographic separation, adsorption, among others, with the liquid-liquid extraction the most commonly used [14]. In fact, for the moment, the recovery of biosurfactants from CSW has been achieved by liquid-liquid extraction with organic solvents. For instance, chloroform or ethyl acetate are used depending on the final application of the biosurfactant, as they are extracellular surface-active compounds [7]. Otherwise, the adsorption onto granular activated carbon [15-18] or ion-exchange resins [19] has also been studied for biosurfactant recovery. The adsorption process is an in situ technique that has certain advantages, such as that it allows the reuse of the adsorbent during several cycles without decreasing adsorption efficiency and avoids the use of organic solvents. Additionally, biosurfactants can be desorbed from the solid adsorbent using typically an aqueous $\mathrm{pH}$ buffer solution due to their lipophilic properties $[15,16,19,20]$. Despite this, new processes have been developed to recover biosurfactants based on cost-effective and environmentally friendly in situ downstream processing approaches. Examples are foam fractionation and membrane technology [20-22]. With regard to membrane technology, ultrafiltration membranes have been remarkably applied for the recovery and purification of glycolipid and lipopeptide biosurfactants [23-26].

From a sustainable point of view, there is an effort to develop more green membranes using biodegradable polymers such as alginate. Specifically, sodium alginate is a natural polysaccharide obtained from the cell wall of brown algae and is an unbranched binary copolymer of 1-4 linked $\beta$-D-mannuronic acid and $\alpha$-L-guluronic acid. The combination of these blocks determines the physical and chemical properties of this polymer [27]. For instance, Aburabie et al. [28] developed calcium alginate-based membranes by crosslinking sodium alginate in calcium chloride aqueous solution, for green organic solvent nanofiltration application to test the retention or permeation of dyes and vitamin B12 in methanol. 
In view of the aforementioned information, the aim of this work is to evaluate calcium alginate-based biopolymers, without or with the presence of biodegraded grape marc, for the recovery of biosurfactants from corn steep water by adsorption processes as a previous step to their use as potential materials in the manufacture of green membranes, and their subsequent use in the recovery of these biomolecules. It should be highlighted that this is the first time that biosurfactants from corn steep water have been recovered by liquid-solid processes without the use of organic solvents.

\section{Materials and Methods}

\subsection{Corn Steep Water}

The corn steep water (CSW) was provided by the FeedStimulants company (Zoetermeer, The Netherlands; Lot No. CSL-201811; Reg. No. NI214247). CSW, containing 50\% of solids $(\mathrm{m} / \mathrm{v})$, was diluted in distilled water up to $50 \mathrm{~g} / \mathrm{L}$, and then it was centrifugated (Hettich Rotina 380R), at $5000 \mathrm{rpm}$ and $4{ }^{\circ} \mathrm{C}$ for $30 \mathrm{~min}$, for solid removal.

The characterization of the CSW, before and after adsorption processes, was carried out by using infrared spectroscopy and mass spectrophotometry analysis.

\subsubsection{Fourier-Transform Infrared Spectroscopy (FTIR)}

A pellet was obtained after pressing $1 \mathrm{mg}$ of the lyophilized sample with $10 \mathrm{mg}$ of potassium bromide. After that, the infrared absorption analysis was carried out with a Niocolet 6700 FTIR system (Thermo Fisher Scientific, Waltham, MA, USA). The spectra were recorded with a resolution of $4 \mathrm{~cm}^{-1}$ and wavenumber range between 400 and $4000 \mathrm{~cm}^{-1}$.

\subsubsection{Electrospray Ionization Mass Spectrometry (ESI-MS)}

Electrospray ionization mass spectrometry/collision-induced dissociation (ESI-MS/CID) was used to characterize the corn stream. For that, $1 \mathrm{mg}$ of the lyophilized sample was diluted in Milli-Q water and volatilized under vacuum. Then, a current of electrons was used to ionize the molecules, and the fragmentation pattern was recorded on a Mass Spectrometer Bruker FTMS APEXIII (Bruker, Billerica, MA, USA) in positive mode.

\subsection{Calcium Alginate-Based Biopolymers}

The biopolymers were formulated using $2 \%$ sodium alginate, whereas biopolymers in combination with other biomaterial (e.g., grape marc) was formulated with $2 \%$ sodium alginate $(\mathrm{m} / \mathrm{v})$ and $2 \%$ biodegraded grape marc $(\mathrm{m} / \mathrm{v})$. Calcium alginate-based biopolymers were formulated using water as a solvent and calcium chloride solution $(0.58 \mathrm{~mol} / \mathrm{L})$ as a crosslinking agent. Furthermore, grape marc was obtained from local winery industries and subjected to a spontaneous biodegradation of the organic matter following the protocol described previously $[29,30]$.

\section{Biopolymers Morphology Characterization}

The biopolymers were washed with sodium cacodylate $0.1 \mathrm{~mol} / \mathrm{L}$ buffer and fixed with $2.5 \%$ of glutaraldehyde in cacodylate $0.1 \mathrm{~mol} / \mathrm{L}$ buffer for $2-4 \mathrm{~h}$ at $4{ }^{\circ} \mathrm{C}$. Following this, the samples of biopolymer were introduced in $1 \% \mathrm{OsO}_{4}$ in cacodylate $0.1 \mathrm{~mol} / \mathrm{L}$ buffer during for $1 \mathrm{~h}$ at $4{ }^{\circ} \mathrm{C}$. Dehydration was carried out with ethanol using a different graded series (30\%-15 min; 50\%-2 × $15 \mathrm{~min} ; 70 \%-2 \times 15 \mathrm{~min} ; 80 \%-2 \times 15 \mathrm{~min} ; 90 \%-2 \times 15 \mathrm{~min}$; $100 \%-3 \times 15 \mathrm{~min})$. Then, samples were dried at the chamber of a critical point dryer (Baltec CPD030, Rambouillet, France) using liquid $\mathrm{CO}_{2}$. Dried samples were cut with liquid $\mathrm{N}_{2}$, covered with gold (Emitech K550X, Dubai, United Arab Emirates) and observed using a digital microscope with a DeltaPix camera (Infinity X21) as well as a scanning electron microscope (SEM) (JEOL JSM 6700F FEG) operating at an acceleration voltage of $5.0 \mathrm{kV}$ for secondary-electron imaging (LEI). 


\subsection{Adsorption Studies}

Adsorption experiments were carried out in $250 \mathrm{~mL}$ Erlenmeyer flasks placed in an orbital shaker (IKA KS 4000 ic control) at $150 \mathrm{rpm}$ and $25^{\circ} \mathrm{C}$. The CSW/biopolymer ratio used was 1:1 $(v / v)$. Samples were removed after $24 \mathrm{~h}$, once the equilibrium was reached, for analysis of biosurfactant extract and other inorganic solutes and biomolecules. Experiments were carried out in triplicate.

Adsorption Removal and Capacity Determination

Equation (1) was used to determine the percentage of inorganic solutes and biomolecules removed from the corn stream, whereas Equation (2) was used to calculate the adsorption capacity qe $(m g / g)$ of calcium alginate-based biopolymers [31]:

$$
\mathrm{C}_{\text {removed }}(\%)=\frac{\mathrm{C}_{0}-\mathrm{C}_{\mathrm{t}}}{\mathrm{C}_{0}} \cdot 100
$$

where $\mathrm{C}_{0}$ and $\mathrm{C}_{\mathrm{t}}(\mathrm{mg} / \mathrm{L})$ are the concentration of inorganic solutes and biomolecules in CSW initially and at a fixed time $t$, respectively.

$$
\mathrm{q}_{\mathrm{e}}\left(\frac{\mathrm{mg}}{\mathrm{g}}\right)=\frac{\left(\mathrm{C}_{0}-\mathrm{C}_{\mathrm{e}}\right) \cdot \mathrm{V}}{\mathrm{W}}
$$

where $C_{0}$ and $C_{e}(\mathrm{mg} / \mathrm{L})$ are the initial and equilibrium concentrations of inorganic solutes and biomolecules in the corn steep water, respectively, V (L) is the volume of the CSW used during adsorption experiments and $\mathrm{W}(\mathrm{g})$ is the mass of biopolymer (expressed as $\mathrm{g}$ of initial sodium alginate).

\subsection{Extraction of Biosurfactants from Corn Steep Water}

For comparative purposes, the lipopeptide biosurfactant extract was obtained by liquid-liquid extraction from CSW, using a ratio chloroform/CSW of 2:1 (v/v), at a temperature of $56^{\circ} \mathrm{C}$, for $60 \mathrm{~min}$ and at an agitation speed of $150 \mathrm{rpm}$. After extraction, the biosurfactant was separated from the chloroform by rotary evaporation (Buchi R-210, Flawil, Switzerland) at a pressure of $474 \mathrm{mbar}$ and $60^{\circ} \mathrm{C}$, following the methodology proposed by Vecino et al. [7]. This biosurfactant extract was used as a control to determine the quantity of biosurfactant present in the initial CSW and after adsorption processes.

Surface Activity and Critical Micellar Concentration Determination

The presence of biosurfactants in the CSW (liquid samples) was observed by surface tension measurements using a Krüss K20 EasyDyne tensiometer with a $1.9 \mathrm{~cm}$ platinum Wilhelmy plate (Krüss GmbH, Hamburg, Germany). Additionally, the critical micellar concentration (CMC) of lyophilized initial CSW and lyophilized samples after adsorption processes as well as the lipopeptide biosurfactant extract, from the CSW using liquid-liquid extraction, were determined after several dilutions in deionized water. The concentration above which micelles are formed is defined as the CMC. Below the CMC, surface tension in aqueous solution decreases. Once the $\mathrm{CMC}$ is reached, surface tension remains more or less constant. Therefore, it is possible, under the CMC, to linearly relate the surface tension with the concentration of biosurfactant [1]. In this case, a calibration curve under the CMC from the biosurfactant extract obtained by liquid-liquid extraction is used to extrapolate the surface tension of liquid samples, before and after adsorption processes, in order to determine the biosurfactant concentration. All determinations were carried out in triplicate.

\subsection{Measurement of Other Inorganic Solutes and Biomolecules from Corn Steep Water}

The determination of other inorganic solutes and biomolecules from CSW (liquid samples) such as organic acids, sugars as well as total organic carbon (TOC), total nitrogen 
(TN), anions, cations, and metal ions before and after adsorption processes, were carried out as follows:

\subsubsection{TOC and TN}

The Analytik Jena 3100 Multi N/C Analyzer was used to determine the carbon and nitrogen content of aqueous samples. The determination was carried out by thermocatalytic decomposition (oxidation) of the samples at $950{ }^{\circ} \mathrm{C}$ as it allows the quantitative determination of even poorly oxidizable carbon and nitrogen components.

\subsubsection{Anions, Organic Acids and Sugars}

The determination and quantification of the anion, organic acids and sugars were carried out by ion chromatography with the DIONEX ICS-3000 equipment. For anion determination, a Metrosep A Supo 5 column $(250 \times 4 \mathrm{~mm}$ Metrohm $)$ with carbonatebicarbonate buffer solution in a mobile phase at $0.7 \mathrm{~mL} / \mathrm{min}$ and conductivity as detector were used. For organic acid determination, an IonPac AS11-HC column $(250 \times 4 \mathrm{~mm}$ Dionex) with $50 \mathrm{mM} \mathrm{NaOH}$ solution as a mobile phase at $1.0 \mathrm{~mL} / \mathrm{min}$ and conductivity as detector were applied. For sugar determination, a CarboPac PA1 column $(250 \times 4 \mathrm{~mm}$ Dionex) with $150 \mathrm{mM} \mathrm{NaOH}$ solution as a mobile phase at $1.0 \mathrm{~mL} / \mathrm{min}$ and amperometric as a detector were utilized.

\subsubsection{Cations and Metals}

Cations and metals were determined and quantified by inductively coupled plasma emission spectroscopy (Optima 4300DV de PerKin Elmer, Waltham, MA, USA). Prior to ICP-OES analyses, samples were filtered $(0.2 \mu \mathrm{m})$ and acidified with $2 \% \mathrm{HNO}_{3}$.

\section{Results and Discussion}

\subsection{Corn Steep Water Composition}

The composition of CSW results in the extraction of water-soluble components during the steeping step of corn, as shown in Table 1. The CSW is mainly composed of carbon (around 37\%) and nitrogenous (about 7\%) components (elemental analysis data not shown), being the total carbon from organic sources. Regarding organic acids, lactic acid is the most predominant one $(6.7 \mathrm{~g} / \mathrm{L})$, followed by the phytic acid $(3.1 \mathrm{~g} / \mathrm{L})$ and acetic acid $(2.8 \mathrm{~g} / \mathrm{L})$. Monosaccharides, like glucose $(0.3 \mathrm{~g} / \mathrm{L})$ and arabinose $(0.2 \mathrm{~g} / \mathrm{L})$, as well disaccharides such as sucrose $(0.04 \mathrm{~g} / \mathrm{L})$ are part of the CSW composition. Physiologically relevant ions such as chloride, phosphate, sulphate, ammonium, calcium, boron, iron, potassium, magnesium, sodium, manganese, zinc, and silicon, were detected in CSW at substantial quantities. Among them, potassium $(0.8 \mathrm{~g} / \mathrm{L})$ and phosphate $(0.5 \mathrm{~g} / \mathrm{L})$ are the most significant; while aluminum, chromium, copper, cobalt, and nickel are the less represented. Hull and Montgomery [32] suggested that the high amount of inorganic phosphate in CSW could be due to in part to being a product of dephosphorylation of myo-inositol phosphates.

The above composition agrees with the composition analyzed by Hull et al. [33] at various times during the steeping of corn and from four different industrial processes. However, the novelty of this composition is the concentration of biosurfactant. This bioactive compound is present in a concentration of $2 \mathrm{~g} / \mathrm{L}$, based on the CMC data of biosurfactant extracted from con steep water by liquid-liquid extraction with chloroform (see Figure S1). This finding, related with the use of CSW as a direct source of biosurfactants, and its uses have been previously patented and published by Vecino et al. [1,7,34]. Nowadays, depending on the industrial application of the biosurfactant extract from CSW, an organic solvent is proposed for the extraction process. However, the possibility of using a liquidsolid extraction process by calcium alginate-based biopolymers to recover biosurfactants from CSW has not been considered until now. 
Table 1. Chemical composition of diluted (20 times) raw corn steep water used in this study after solid removal.

\begin{tabular}{cc}
\hline Component & Concentration (mg/L) \\
\hline Biosurfactant extract & $2007 \pm 39$ \\
Total organic carbon & $5613 \pm 45$ \\
Total nitrogen & $1655 \pm 21$ \\
Lactic acid & $6714 \pm 394$ \\
Acetic acid & $2822 \pm 1$ \\
Formic acid & $4.9 \pm 0.7$ \\
Phytic acid & $3141 \pm 3$ \\
Arabinose & $204 \pm 5$ \\
Glucose & $287 \pm 10$ \\
Sucrose & $41 \pm 3$ \\
Chloride & $163 \pm 3$ \\
Phosphate & $511 \pm 16$ \\
Sulphate & $242 \pm 8$ \\
Ammonium & $183 \pm 4$ \\
Calcium & $3.6 \pm 0.2$ \\
Aluminum & $0.1 \pm 0.005$ \\
Boron & $0.7 \pm 0.03$ \\
Chromium & $0.03 \pm 0.001$ \\
Copper & $0.07 \pm 0.003$ \\
Iron & $3.1 \pm 0.1$ \\
Cobalt & $\mathrm{ND} *$ \\
Potassium & $847 \pm 45$ \\
Magnesium & $301 \pm 15$ \\
Sodium & $183 \pm 1$ \\
Manganese & $1.5 \pm 0.1$ \\
Nickel & $0.09 \pm 0.005$ \\
Zinc & $4.9 \pm 0.2$ \\
Silicon & $8.0 \pm 0.4$ \\
\hline Pon &
\end{tabular}

$\mathrm{ND}^{*}=$ below the limit of quantification $(0.01 \mathrm{mg} / \mathrm{L})$.

\subsection{Calcium Alginate-Based Biopolymers Characterization}

The macro view as well as the SEM images of the calcium alginate-based biopolymers formulated without (Figure 1a,c,e) shows and with the presence of grape marc (Figure $1 \mathrm{~b}, \mathrm{~d}, \mathrm{f}$ ) are shown in Figure 1 . Figure $1 \mathrm{a}, \mathrm{b}$ show the macro view images of the calcium alginate-based biopolymers. The presence of the biodegradable material (e.g., grape marc) can be observed in Figure $1 \mathrm{~b}$ through black dot visualization. Figure $1 \mathrm{c}, \mathrm{d}$ shows the external morphology of biopolymers at $300 \times$ magnification; whereas Figure 1e,f shows the internal morphology of biopolymers at $1000 \times$ magnification. Taking into to account the images above, it can be observed that the calcium alginate-based biopolymer in the presence of grape marc is a heterogeneous biopolymer; while the biopolymer composed of by alginate is a homogeneous biopolymer. Both biopolymers have rough surfaces, but the polymer with grape marc has a rougher surface (see Figure 1c,d). The morphology observed, in the case of biopolymer of alginate tunned with grape marc, is in concordance with the characterization of this biopolymer in previous studies [30].

\subsection{Calcium Alginate-Based Biopolymers Performance in Liquid-Solid Process to Recover} Biosurfactants from Corn Steep Water

In this study, two types of calcium alginate-based biopolymers were formulated without and with the presence of grape marc for the recovery of biosurfactants in CSW. Table 2 shows the removal percentage of the inorganic solutes and biomolecules, that comprise CSW, after adsorption process for a contact time for $24 \mathrm{~h}$ (e.g., equilibrium was attained), using alginate biopolymer and alginate biopolymer with grape marc. 

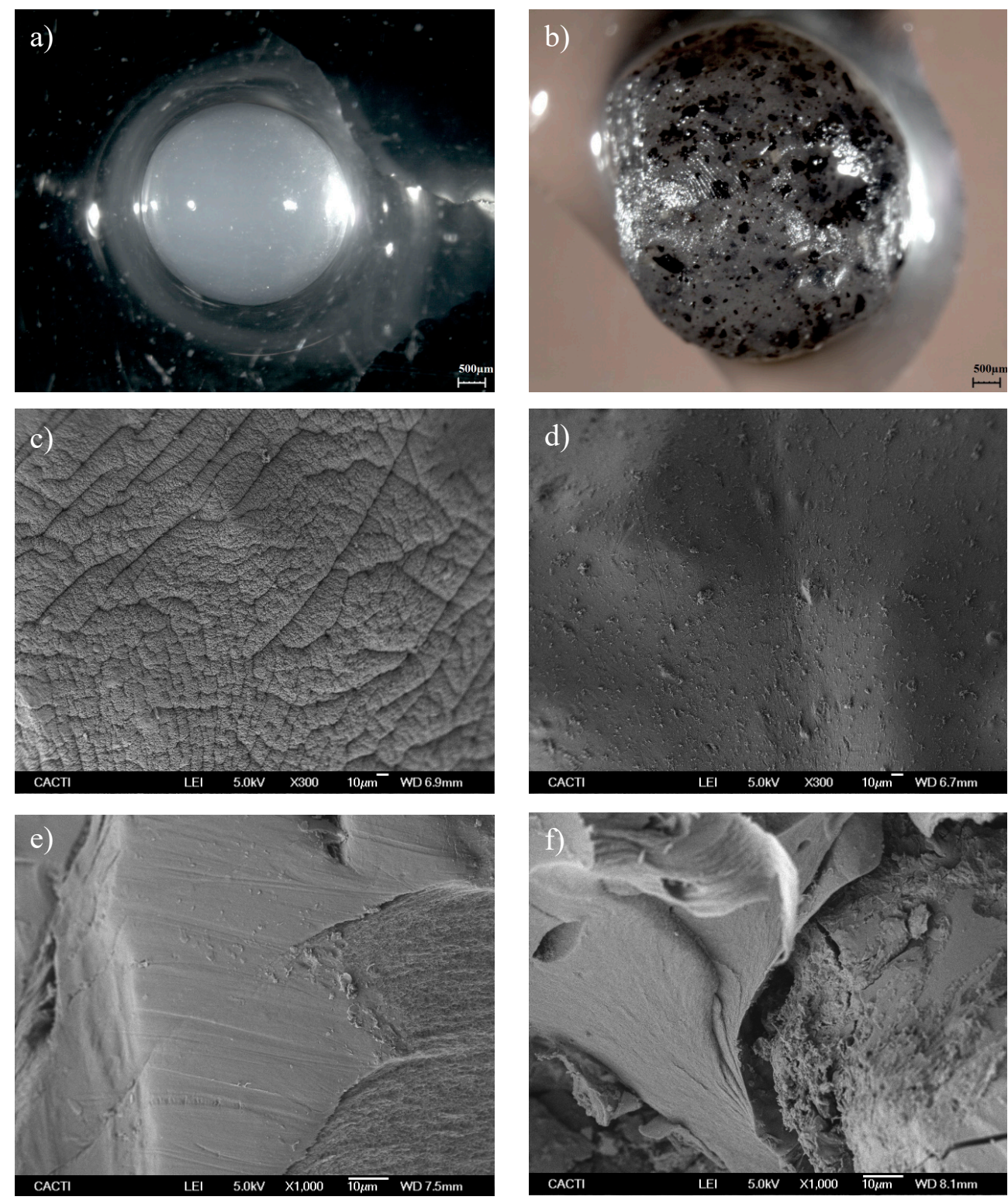

Figure 1. Macro view and SEM micrographs of alginate-based biopolymers: $(\mathbf{a}, \mathbf{c}, \mathbf{e})$ from the biopolymer composed only for alginate, and $(\mathbf{b}, \mathbf{d}, \mathbf{f})$ from the biopolymer with alginate and grape marc.

The biopolymer that only contains alginate presented a high capacity for the elimination of organic acids and sugars from the CSW, with a maximum removal for acetic acid $(100 \%)$ and glucose $(98.5 \%)$, respectively. For almost all ions, metals as well as biosurfactant extract, the percentage of removal was about $50 \%$, except for boron $(40.4 \%)$ and silicon $(39.2 \%)$. On the other hand, the alginate-based biopolymer tunned with grape marc, also showed good elimination rates for the same families, organic acids, and sugars, but for other types. For instance, the highest percentage of elimination was for lactic acid (99\%) and for all the sugars tested this was greater than $99 \%$. Moreover, this biopolymer had obtained good removal of metals such as iron $(98.5 \%)$ and zinc $(96.8 \%)$ as well as for cations, like manganese $(90.4 \%)$, and anions, such as phosphate (75\%). However, the amount of biosurfactant extract eliminated was of $55 \%$. 
Table 2. Removal of some inorganic solutes and biomolecules (\%) with the calcium alginate-based biopolymers after $24 \mathrm{~h}$ of equilibration time.

\begin{tabular}{ccc}
\hline Component & Alginate Biopolymer (\%) & Alginate Biopolymer with Grape Marc (\%) \\
\hline Biosurfactant & $46.6 \pm 1.5$ & $54.6 \pm 1.5$ \\
Total organic carbon & $36.7 \pm 0.5$ & $48.8 \pm 0.1$ \\
Total nitrogen & $42.7 \pm 2.4$ & $57.5 \pm 0.2$ \\
Lactic acid & $50.0 \pm 1.6$ & $99.0 \pm 0.1$ \\
Acetic acid & $100 \pm 0.1$ & $83.8 \pm 2.6$ \\
Formic acid & $73.7 \pm 4.3$ & $69.1 \pm 3.9$ \\
Phytic acid & $72.7 \pm 0.1$ & $82.6 \pm 1.7$ \\
Arabinose & $88.5 \pm 0.6$ & $99.2 \pm 0.1$ \\
Glucose & $98.5 \pm 0.6$ & $99.4 \pm 0.2$ \\
Sucrose & $92.5 \pm 1.8$ & $99.8 \pm 0.1$ \\
Phosphate & $59.1 \pm 1.1$ & $75.1 \pm 0.5$ \\
Sulphate & $48.5 \pm 2.2$ & $42.0 \pm 1.0$ \\
Ammonium & $44.0 \pm 1.4$ & $27.1 \pm 1.5$ \\
Boron & $40.4 \pm 0.8$ & $8.8 \pm 0.4$ \\
Iron & $77.0 \pm 0.1$ & $98.5 \pm 0.1$ \\
Potassium & $49.2 \pm 0.5$ & $54.9 \pm 0.4$ \\
Magnesium & $45.8 \pm 0.2$ & $66.0 \pm 0.3$ \\
Manganese & $62.2 \pm 0.2$ & $90.4 \pm 0.7$ \\
Zinc & $58.9 \pm 1.4$ & $96.8 \pm 0.2$ \\
Silicon & $39.2 \pm 0.4$ & $10.1 \pm 0.5$
\end{tabular}

Overall, the combination of calcium alginate-based biopolymer with grape marc provided better results in comparison with only calcium alginate biopolymer; except for boron and silicon, where only the alginate biopolymer offered greater affinity for these compounds. The initial hypothesis is supported by the fact that grape marc possesses lower adsorption capacity for these elements than calcium alginate, which reduces the adsorption capacity for boron and silicon. When the bio-adsorbent is formulated with sodium alginate, the active surface sites for adsorption are based only in the calcium alginate-based polymer, whereas when the bioadsorbent is formulated with sodium alginate $(2 \%)$ plus grape marc $(2 \%)$, the active surface sites, for adsorption, based on calcium alginate, were lower, since the latter biopolymer has a lower percentage of alginate, with respect to the total composition, than the former. Additionally, the adsorption of biosurfactant extract was not greatly influenced by the type of biopolymer since there was only around $8 \%$ difference between them. Indeed, it is important to remark that this is a multi-adsorption mechanism, occurring simultaneously with physical and/or chemical adsorption and ion-exchange processes. Moreover, the corn stream is composed of several inorganic solutes and biomolecules that interact between them, adding more complexity to the adsorption process. However, in a previous study [30], a calcium alginate-based biopolymer tunned with grape marc was evaluated for the removal of color in wastewater. It was observed that the adsorption process followed a pseudo-second order kinetic model (heterogeneous process). In addition, in another physicochemical study with a bio-based adsorbent made from grape marc [35], the physical control of the sorption stage was well- described by the Freundlich isotherm.

Biodegraded grape marc entrapped in calcium alginate beads has been previously tested as an eco-adsorbent. For instance, Perez-Ameneiro et al. evaluated the use of a biopolymer based on grape marc entrapped in calcium alginate beads for the removal of pigments from an agro-industrial effluent [30] or dye compounds from winery wastewater [35] as well as to remove micronutrients from winery effluents in order to avoid eutrophication [36]. Additionally, an alginate-based polymer with grape marc has also been tested as an eco-adsorbent for removal of copper (II) from aqueous streams [37]; for adsorption of binary mixtures of dyes [38]; and for the removal of cyanide and transition metals from industrial electroplating process waters [39]. Nevertheless, it should be high- 
lighted that this type of biopolymer has never been tested to recover biosurfactants present in corn steep water.

In the case study of micronutrients [36], the calcium alginate-based biopolymer with grape marc removed most of the $\mathrm{TN}, \mathrm{NH}_{4}{ }^{+}$and $\mathrm{NO}_{3}{ }^{-}$existing in the vinasses (wastewater from winery industry) and about $60 \%$ of $\mathrm{Mg}, \mathrm{P}, \mathrm{K}$, and total carbon. Similar results were obtained in the current study, with $66 \%$ of $\mathrm{Mg}, 75 \%$ of $\mathrm{P}, 55 \%$ of $\mathrm{K}$ and $49 \%$ of TOC. It is important to note that in the corn steep water, the concentration of $\mathrm{Mg}$ and $\mathrm{P}$ was almost ten times more, being double for $\mathrm{K}$ and around six times more for the total carbon than vinasses.

On the other hand, the adsorption capacities for the inorganic solutes and biomolecules tested using calcium alginate-based biopolymers, after $24 \mathrm{~h}$ of equilibration time, are displayed in Table 3.

Table 3. Adsorption capacity $(\mathrm{mg} / \mathrm{g}$ ) of some inorganic solutes and biomolecules with the calcium alginate-based biopolymers after $24 \mathrm{~h}$ of adsorption process.

\begin{tabular}{ccc}
\hline Component & Alginate Biopolymer (mg/g) & $\begin{array}{c}\text { Alginate Biopolymer with } \\
\text { Grape Marc (mg/g) }\end{array}$ \\
\hline Biosurfactant & $46.8 \pm 0.4$ & $54.8 \pm 0.6$ \\
Total organic carbon & $102.9 \pm 1.3$ & $136.9 \pm 0.1$ \\
Total nitrogen & $35.3 \pm 2.0$ & $47.6 \pm 0.1$ \\
Lactic acid & $167.9 \pm 5.4$ & $332.4 \pm 0.1$ \\
Acetic acid & $141.1 \pm 0.2$ & $118.2 \pm 3.7$ \\
Phytic acid & $114.2 \pm 0.2$ & $129.7 \pm 2.7$ \\
Arabinose & $9.0 \pm 0.1$ & $10.1 \pm 0.1$ \\
Glucose & $14.1 \pm 0.1$ & $14.3 \pm 0.1$ \\
Sucrose & $1.9 \pm 0.1$ & $2.0 \pm 0.1$ \\
Phosphate & $15.1 \pm 0.3$ & $19.2 \pm 0.1$ \\
Sulphate & $5.9 \pm 0.3$ & $5.1 \pm 0.1$ \\
Ammonium & $4.0 \pm 0.1$ & $2.5 \pm 0.1$ \\
Potassium & $20.8 \pm 0.2$ & $23.3 \pm 0.2$ \\
Magnesium & $6.9 \pm 0.1$ & $9.9 \pm 0.1$ \\
\hline
\end{tabular}

The maximum adsorption capacity was achieved for lactic acid with both biopolymers, which was 167.9 and $332.4 \mathrm{mg} / \mathrm{g}$ for the calcium alginate-based biopolymer without and with grape marc, respectively. This maximum capacity is followed by the capacity for acetic acid (141.1 mg/g) and phytic acid (114.2 mg/g) in the case of the biopolymer alone with alginate; and this order of adsorption capacity value is reversed in the biopolymer containing grape marc: phytic acid with $129.7 \mathrm{mg} / \mathrm{g}$ and acetic acid with $118.2 \mathrm{mg} / \mathrm{g}$. Additionally, both biopolymers presented high capacity for TOC between $102.9 \mathrm{mg} / \mathrm{g}$ (alginate) and $136.9 \mathrm{mg} / \mathrm{g}$ (alginate plus grape marc); and the capacity of TN was 35.3 and $47.6 \mathrm{mg} / \mathrm{g}$ for the alginate biopolymer and the alginate biopolymer tunned with grape marc, respectively. Concerning the biosurfactant adsorption capacity, both biopolymers showed values of 46.8 and $54.8 \mathrm{mg} / \mathrm{g}$ for the alginate biopolymer and the alginate biopolymer tunned with grape marc, respectively. For the other inorganic solutes and biomolecules, that compose the CSW, the calcium alginate-based biopolymers provided adsorption capacities values below $24 \mathrm{mg} / \mathrm{g}$.

Depending on the solute and its concentration, the capacity of calcium alginate-based biopolymer, tunned with grape marc, changes substantially. For example, in the study of pigment removal from vinasses [30], the capacity of the biopolymer varied between 0.28 and $0.76 \mathrm{mg} / \mathrm{g}$ as a function of the initial dye concentration $(8.8$ to $24.7 \mathrm{mg} / \mathrm{L})$. Also, in the case of mixtures of dyes [38], the adsorption capacity was 2.47 and $2.22 \mathrm{mg} / \mathrm{g}$ for methylene blue and methyl red, respectively, using calcium alginate-based biopolymer with grape marc; whereas, the biopolymer based only in calcium alginate achieved capacity values lower than $2 \mathrm{mg} / \mathrm{g}$. These capacities are very low compared to those obtained in this work. However, the biopolymer capacities for metal ions were higher. Pérez-Cid et al. [39] 
concluded that calcium alginate hydrogel beads can be considered a bioadsorbent with a high capacity to remove free cyanide $(1177 \mathrm{mg} / \mathrm{g})$ and transition metals $(\mathrm{Ni}, \mathrm{Cu}$ and $\mathrm{Zn}$ as follows 107.3, 39.5 and $1.52 \mathrm{mg} / \mathrm{g}$, respectively) in electroplating streams. In this case, the introduction of composted grape marc in the calcium alginate bead formulation did not produce significant improvements in the adsorption capacity. Comparatively, the $\mathrm{Zn}$ adsorption capacity, achieved in the current work, was higher $23.9 \mathrm{mg} / \mathrm{g}$, but the initial concentration of zinc in the corn stream was around ten times less and also lower quantity of adsorbent was used (the CSW/biopolymer ratio used was 1:1 (v/v) vs. the wastewater/bioadsorbent ratio used was 1.5:1 (v/v)) than in the previous study. Otherwise, the maximum adsorption capacity was reached by using the calcium alginatebased biopolymer with grape marc for copper (II) removal from sulfate solutions [37]. In this study, the adsorption capacity value was around $1800 \mathrm{mg} / \mathrm{g}$ after $5 \mathrm{~min}$ of contact time, while it increased to $2785 \mathrm{mg} / \mathrm{g}$ at the highest concentration assessed $(0.15 \mathrm{~mol} / \mathrm{L})$ and at the maximum extraction times ( $20 \mathrm{~min}$ ).

\subsection{Characterization of Corn Steep Water before and after Adsorption Processes}

The corn steep waters were characterized based on CMC, FTIR and ESI-MS analysis. Raw corn steep liquor possesses a CMC of 10-15 g/L depending on the provider company, providing minimum surface tension values to water between 36.6 and $46.7 \mathrm{mN} / \mathrm{m}$ [1] However, these results are not comparable with those obtained in this work since the corn steep water has been centrifuged (for solids removal) and lyophilized. Thus, in the current work the CMC of the corn steep water, as shown in Figure 2, was $0.46 \mathrm{~g} / \mathrm{L}$, reaching a minimum surface tension of $54.5 \pm 0.2$, observing that solids increased the CMC of raw corn steep liquor, although they provide a higher reduction of surface tension in water.

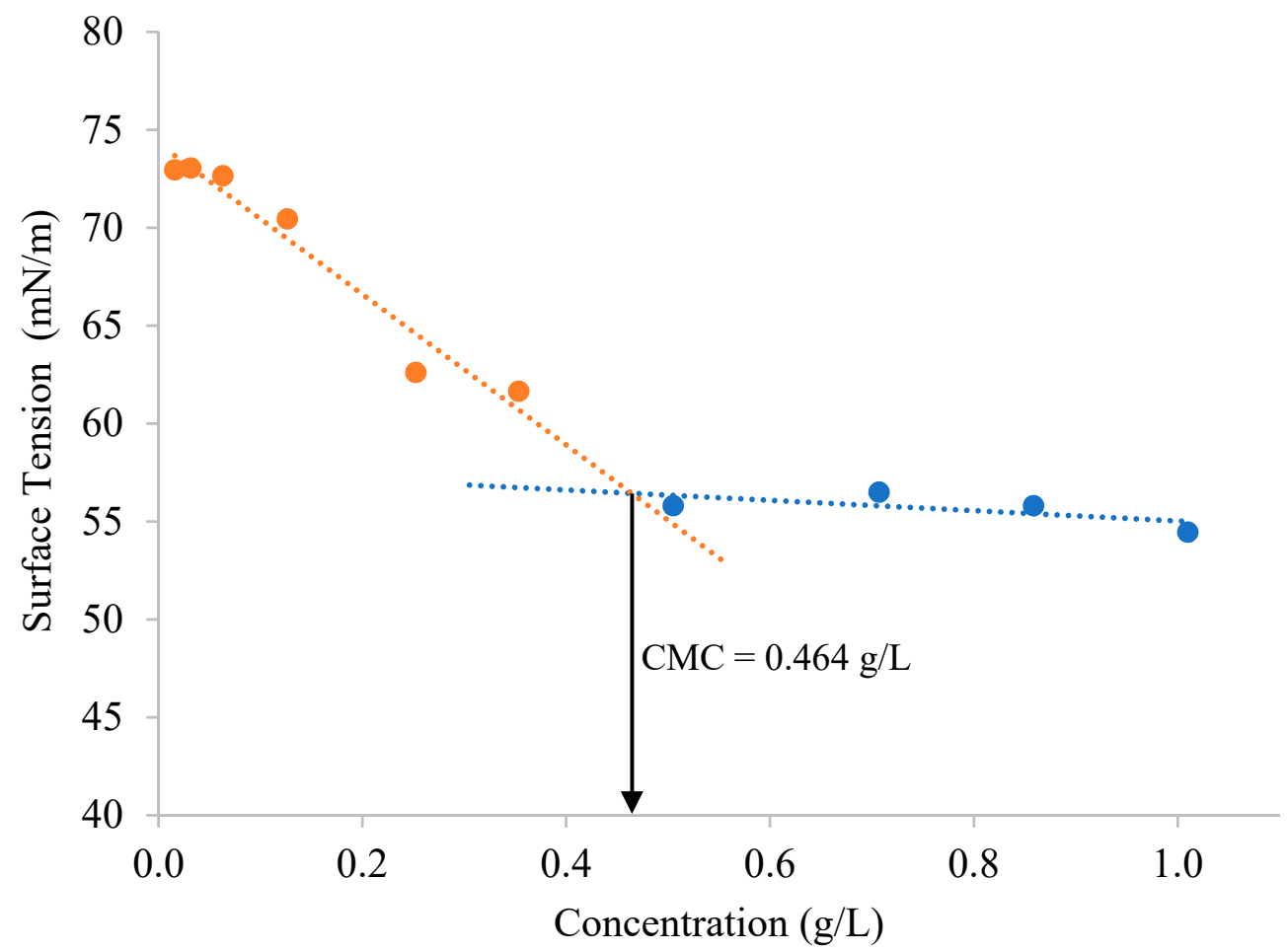

Figure 2. Critical micellar concentration (CMC) of corn steep water before adsorption processes.

The concentration at which the micellization starts is known as CMC. At this concentration not only the micelles are made, but also the lower surface tension value of the solution is achieved [40]. Thus, after the adsorption processes, with the calcium alginatebased biopolymers, the CMC values increased almost two-fold, being 0.99 and $1.15 \mathrm{~g} / \mathrm{L}$ for the biopolymer based on calcium alginate and calcium alginate tunned with grape marc, respectively; whereas the minimum surface tension remained constant $(54.2-55.3 \mathrm{mN} / \mathrm{m})$. 
In this case, although the minimum surface tension value had been kept constant, an increase in CMC implies that a higher amount of biosurfactant extract is needed to reach this value of surface tension. Therefore, the corn steep water reduced its surfactant capacity, since the biosurfactant extract is adsorbed by these calcium alginate-based biopolymers. Thus, CMC results are in concordance with the percentage removal of the biosurfactant as a function of the type of biopolymer (see Table 2). Therefore, greater capacities for biosurfactants obtained with the biopolymers, involved higher CMC values for the treated corn steep water. Although the presence of biosurfactants in those streams treated with calcium alginate polymer tunned with grape marc was lower.

On the other hand, Figure 3 shows the FTIR spectra of the initial corn steep water (grey line) as well as the corn streams after adsorption processes with the calcium alginate-based biopolymers (orange and blue lines). Also, it was used to determine the similarities of the corn stream before and after the adsorption processes.

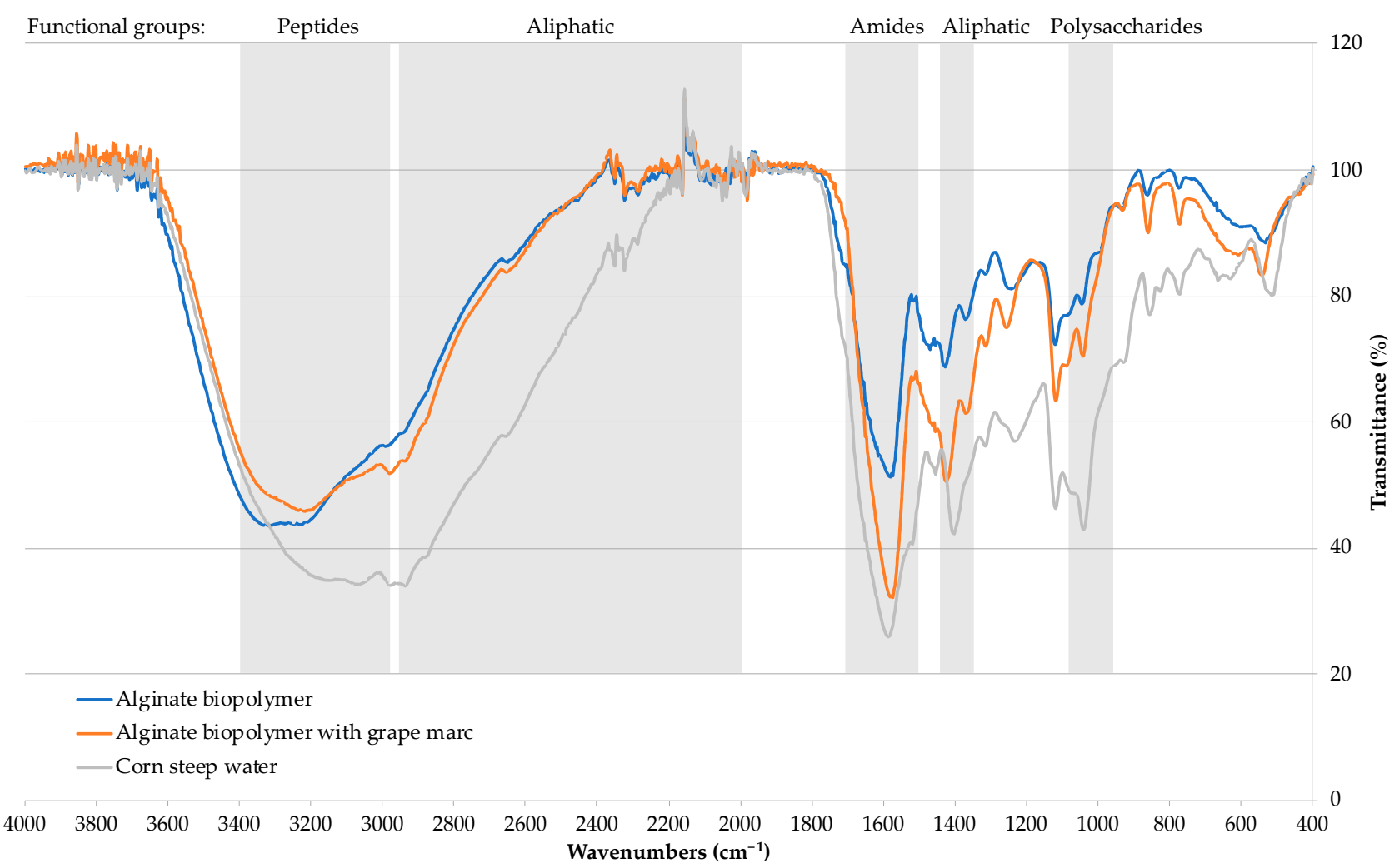

Figure 3. FTIR spectra of corn steep water before and after adsorption processes with calcium alginate-based biopolymers.

The FTIR spectrum of the biopolymer only with alginate is in concordance with the results of characterization carried out by Aburabie et al. [28], where the absorption region of stretching vibrations of $\mathrm{O}-\mathrm{H}$ bonds $\left(3344 \mathrm{~cm}^{-1}\right)$ in calcium alginate membranes was narrower and more elongated than sodium alginate solution; while the $\mathrm{C}-\mathrm{O}$ stretching vibration (1080 and $1021 \mathrm{~cm}^{-1}$ ) decreased in calcium alginate membranes.

In general terms, the bands of corn stream that are affected, after the adsorption process, correspond to the functional groups of proteins, lipids, and polysaccharides. The characterization was as follows: (i) the wavenumbers between 3400 and $3000 \mathrm{~cm}^{-1}$ corresponded with the peptide groups resulting from $\mathrm{O}-\mathrm{H}$ and $\mathrm{N}-\mathrm{H}$ stretching; (ii) bands around 3000 and $2000 \mathrm{~cm}^{-1}$ as well as $1400 \mathrm{~cm}^{-1}$ related to the presence of $\mathrm{C}-\mathrm{H}$ stretching corresponding to aliphatic chains $\left(\mathrm{CH}_{2}\right.$ and $\mathrm{CH}_{3}$ groups) of fatty acids; (iii) the bands $\mathrm{C}=\mathrm{O}$ bond at $1640 \mathrm{~cm}^{-1}$ (amide I bond) and N-H bonds at $1540 \mathrm{~cm}^{-1}$ (amide II bond) indicated the presence of protein-related weakness; and iv) the band around $1000 \mathrm{~cm}^{-1}$ denoted the presence of polysaccharides, conforming the $\mathrm{C}-\mathrm{O}$ stretch vibration $[41,42]$. 
The bands of the three main functional groups (proteins, lipids, and polysaccharides) are decreased after the adsorption process with both calcium alginate-based biopolymers. This is confirmed by the degree of similarity of the initial corn stream before and after adsorption processes, which was $69.6 \%$ and $72.1 \%$ for the biopolymer alone with alginate or alginate tunned with grape marc, respectively between $400-4000 \mathrm{~cm}^{-1}$. It would be expected that the corn stream treated with the alginate-based biopolymer tunned with grape marc would be more different from the initial corn stream, since the removal rates for most of the inorganic solutes and biomolecules were higher than those obtained after treating the corn steep water with the biopolymer only based on calcium alginate (see Table 2). Additionally, the biosurfactant extract obtained from corn steep liquor is a lipopeptide [1]; therefore, observing the protein band, it would be expected that the biopolymer with grape marc would produce a greater reduction in the band of corn steep water, due to the higher removal percentage of biosurfactant achieved in comparison with the biopolymer only formulated with calcium alginate (around 55\% vs. 47\%). This finding could be due to the fact that the calcium alginate-based biopolymer tunned with grape marc provided nitrogen to corn steep water, since grape marc is a biodegradable material with the following composition: $3.9 \% \mathrm{~N}, 42.7 \% \mathrm{C}$ and $5.5 \% \mathrm{H}$ [30].

Moreover, the ESI-MS analysis allowed us to corroborate the adsorption of certain inorganic solutes and biomolecules such as the biosurfactant by the biopolymers under evaluation. Figure 4 shows the natural molecular masses of the bioactive molecules present in the raw corn stream as well as those present in the corn steep water after adsorption treatment with the calcium alginate-based biopolymers. The following signals were detected in raw corn steep water: at 175, 219, 263, 330, 423, 493, 570, 659, 806, 879, 966 as well as signals between $1200-1300 \mathrm{~m} / \mathrm{z}$. Some of them, for instance 879 , were $\mathrm{m} / \mathrm{z}$ also detected in the biosurfactant extract obtained from corn steep liquor, after the liquid-liquid extraction process, in previous studies [43]. In fact, the biomarker observed at $879 \mathrm{~m} / \mathrm{z}$ (and at $617 \mathrm{~m} / \mathrm{z}$ ) was derived from the fragmentation of the signal observed at $933 \mathrm{~m} / \mathrm{z}$, with signals compatible with the presence of lipopeptide biosurfactants [43]. Additionally, Li et al. [44] suggested that the presence of triglycerides, diglycerides and monoglycerides could be signals below $800 \mathrm{~m} / \mathrm{z}$. Ma et al. [45] detected, in the ESI-MS/MS spectrum, at $441 \mathrm{~m} / \mathrm{z}$, several surfactin precursors. Nevertheless, in the biosurfactant extract from CSW, obtained after liquid-liquid extraction with organic solvents, this signal could correspond to the presence of phenolic compounds [46,47].

Otherwise, signals within the range of 800 and $1200 \mathrm{~m} / \mathrm{z}$ are mass biomarkers of biosurfactant precursors produced by Bacillus strains widely described in lipopeptide analyses [44,48-50]. Thus, the masses higher than $800 \mathrm{~m} / \mathrm{z}$ relatively disappeared from the ESI spectrum, in treated corn steep water, corroborating that part of the biosurfactant extract was trapped by the calcium alginate-based biopolymers. 


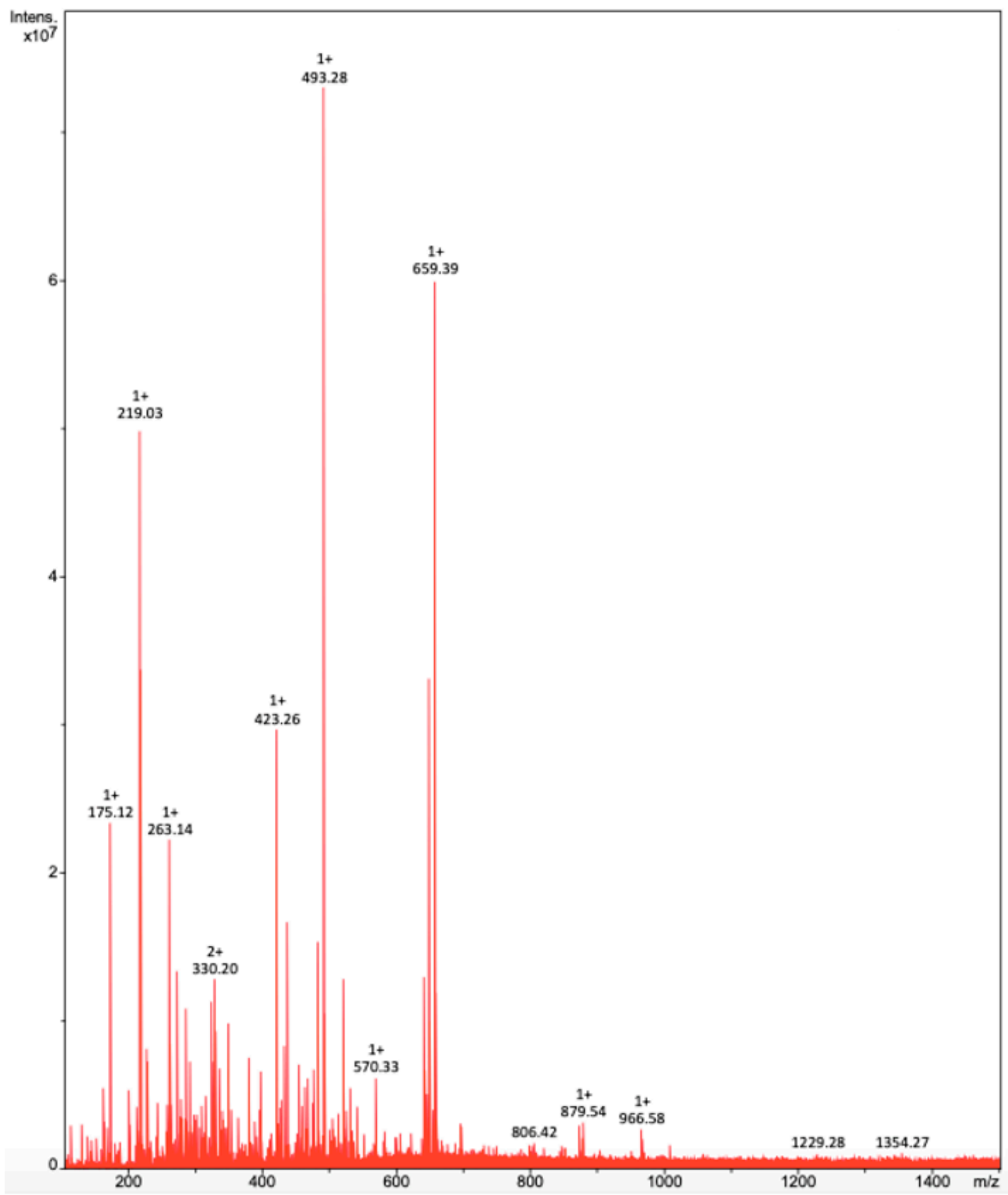

(a)

Figure 4. Cont. 


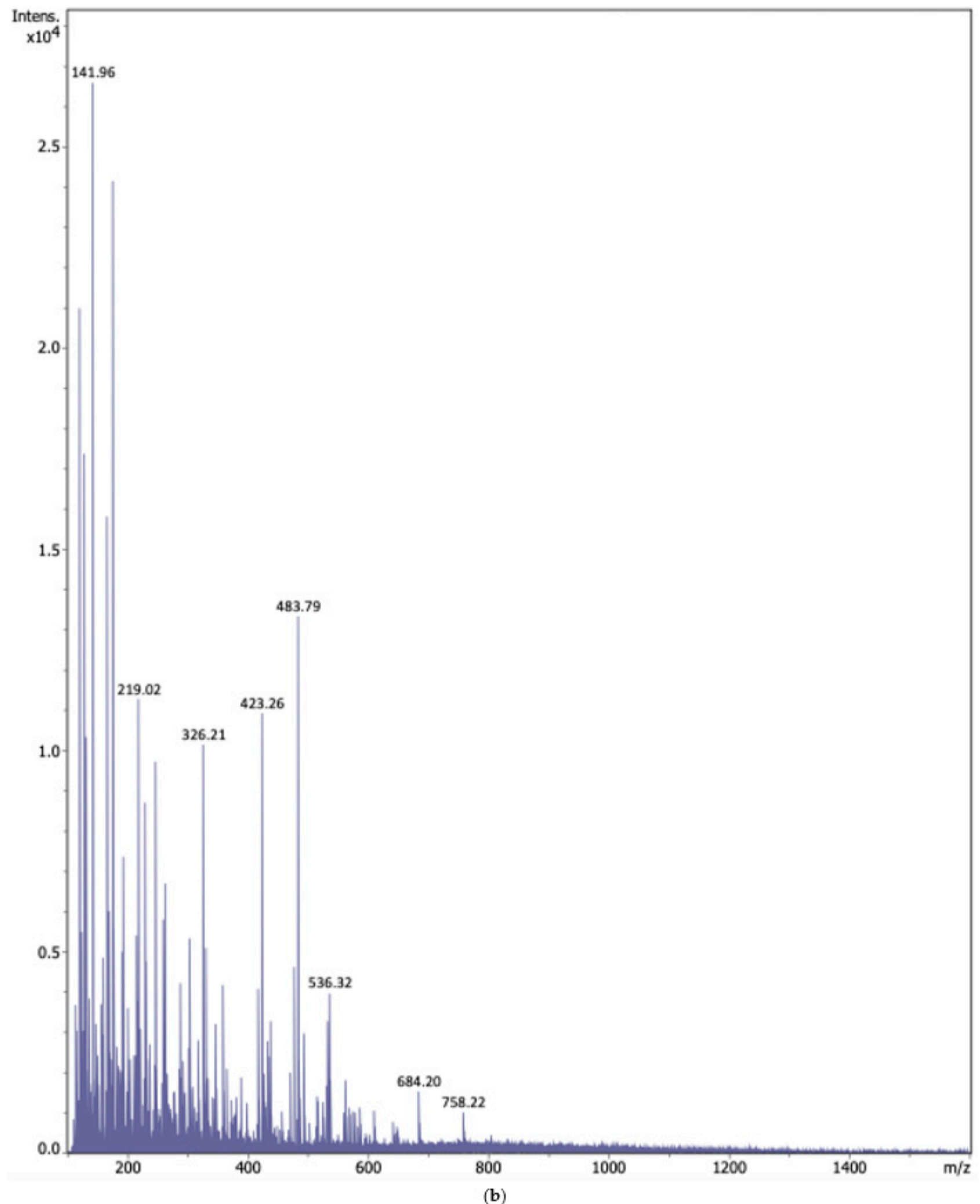

Figure 4. Cont. 


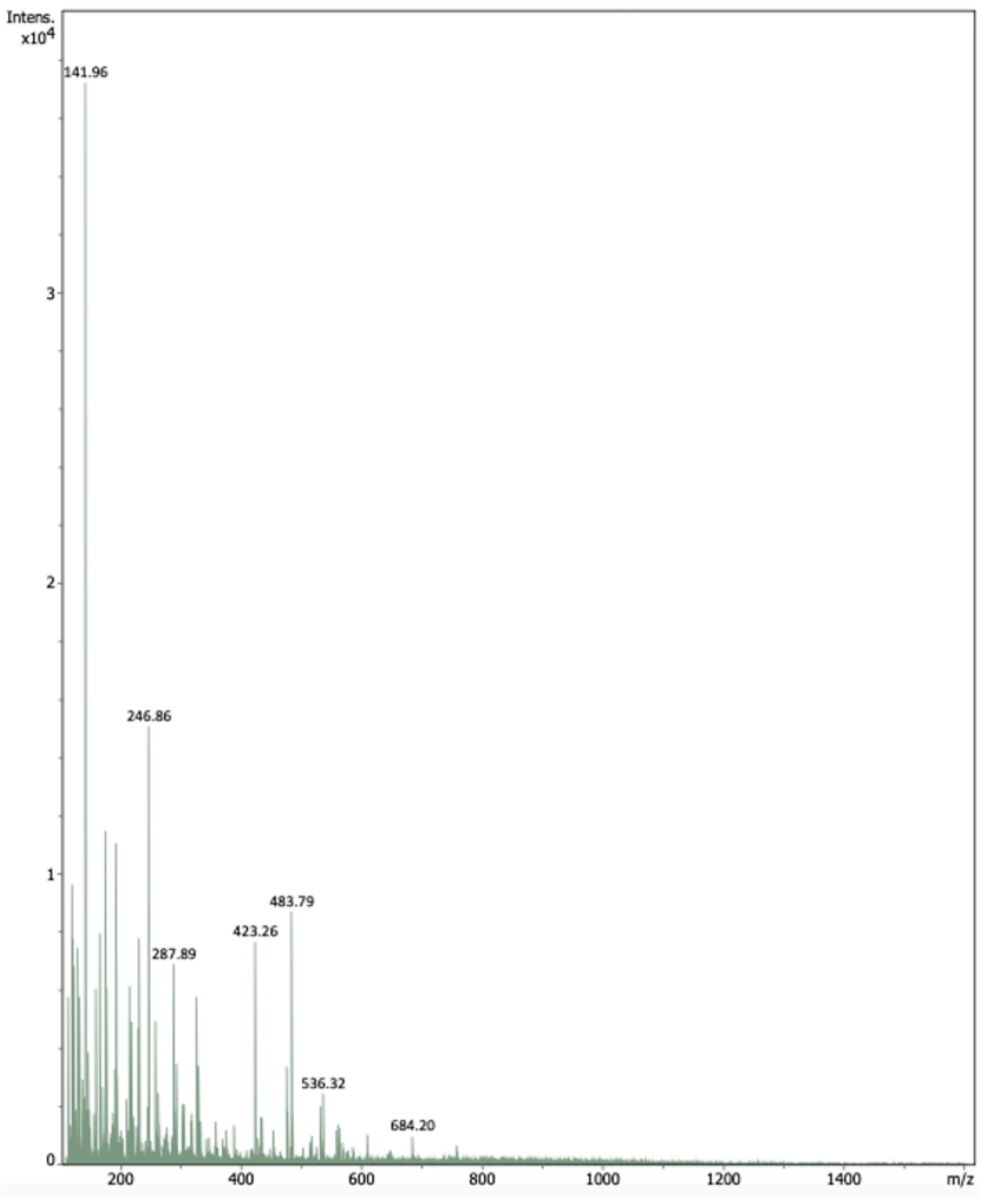

(c)

Figure 4. ESI spectra of raw corn steep water (a) and corn stream after adsorption process with the calcium alginate-based biopolymers, only alginate (b) and alginate tunned with grape marc (c). 


\section{Conclusions}

Corn steep water is an interesting secondary stream obtained from the corn industry and is used as a direct source of biosurfactants. However, nowadays, the recovery of biosurfactants using sustainable processes is a challenge. Thus, this work is a first attempt at recovering biosurfactants from CSW by a liquid-solid process using calcium alginatebased biopolymers, without or with an additive (e.g., biodegraded grape marc). The results achieved showed that calcium alginate-based biopolymers possess an enormous potential to enhance the capabilities of membranes prepared from green materials. Based on the results obtained in this work, several scenarios can be proposed for the use of these biopolymers: i) as a polishing step before biosurfactant recovery to remove impurities such as organic acids, sugars as well as cations, metals, and anions from CSW; and ii) as a recovery step for biosurfactant extract since about $50 \%$ is removed. Overall, it could be highlighted that it is possible to recover biosurfactants, avoiding organic solvents, with biodegradable materials. Although more studies are needed in order to design the alginate-based membranes, as well as the eluent used for the desorption process.

Supplementary Materials: The following are available online at https:/ /www.mdpi.com/article/ 10.3390/w13172396/s1, Figure S1: Critical micellar concentration (CMC) of biosurfactant extract obtained from corn steep water after liquid-liquid extraction with chloroform.

Author Contributions: Conceptualization, A.M.-A., M.R., J.M.C., J.L.C., A.B.M. and X.V.; methodology, A.M.-A.; validation, A.M.-A., J.M.C., A.B.M. and X.V.; formal analysis, A.M.-A., A.B.M. and X.V.; investigation, A.M.-A., M.R., J.M.C., J.L.C., A.B.M. and X.V.; resources, J.M.C. and A.B.M.; Writing-Original draft preparation, X.V.; Writing-Review and editing, A.M.-A., M.R., J.M.C., J.L.C., A.B.M. and X.V.; visualization, J.L.C., A.B.M. and X.V.; supervision, A.B.M. and X.V.; project administration, X.V.; funding acquisition, X.V. All authors have read and agreed to the published version of the manuscript.

Funding: This research was funded by the Spanish Ministry of Science and Innovation under the project PID2019-103873RJI00/AEI/10.13039/501100011033, and by the Xunta de Galicia under the project GPC-ED431B 2020/17.

Institutional Review Board Statement: Not applicable.

Informed Consent Statement: Not applicable.

Data Availability Statement: The data presented in this study is available on request from the corresponding author.

Conflicts of Interest: The authors declare no conflict of interest.

\section{References}

1. Vecino, X.; Barbosa-Pereira, L.; Devesa-Rey, R.; Cruz, J.M.; Moldes, A.B. Study of the Surfactant Properties of Aqueous Stream from the Corn Milling Industry. J. Agric. Food Chem. 2014, 62, 5451-5457. [CrossRef]

2. Rivas, B.; Moldes, A.B.; Domínguez, J.M.; Parajó, J.C. Development of Culture Media Containing Spent Yeast Cells of Debaryomyces Hansenii and Corn Steep Liquor for Lactic Acid Production with Lactobacillus Rhamnosus. Int. J. Food Microbiol. 2004, 97, 93-98. [CrossRef]

3. Gudiña, E.J.; Fernandes, E.C.; Rodrigues, A.I.; Teixeira, J.A.; Rodrigues, L.R. Biosurfactant Production by Bacillus Subtilis Using Corn Steep Liquor as Culture Medium. Front. Microbiol. 2015, 6, 1-7. [CrossRef]

4. Wang, G.; Shi, B.; Zhang, P.; Zhao, T.; Yin, H.; Qiao, C. Effects of Corn Steep Liquor on $\beta$-Poly(l-Malic Acid) Production in Aureobasidium Melanogenum. AMB Express 2020, 10, 1-10. [CrossRef] [PubMed]

5. Azizi-Shotorkhoft, A.; Sharifi, A.; Mirmohammadi, D.; Baluch-Gharaei, H.; Rezaei, J. Effects of Feeding Different Levels of Corn Steep Liquor on the Performance of Fattening Lambs. J. Anim. Physiol. Anim. Nutr. 2016, 100, 109-117. [CrossRef] [PubMed]

6. Ullah, Z.; Yousaf, M.; Shami, M.M.; Sharif, M.; Mahrose, K. Effect of Graded Levels of Dietary Corn Steep Liquor on Growth Performance, Nutrient Digestibility, Haematology and Histopathology of Broilers. J. Anim. Physiol. Anim. Nutr. 2018, 102, e395-e402. [CrossRef] [PubMed]

7. Vecino, X.; Barbosa-Pereira, L.; Devesa-Rey, R.; Cruz, J.M.; Moldes, A.B. Optimization of Liquid-Liquid Extraction of Biosurfactants from Corn Steep Liquor. Bioprocess. Biosyst. Eng. 2015, 38, 1629-1637. [CrossRef] [PubMed]

8. López-Prieto, A.; Martínez-Padrón, H.; Rodríguez-López, L.; Moldes, A.B.; Cruz, J.M. Isolation and Characterization of a Microorganism That Produces Biosurfactants in Corn Steep Water. CyTA-J. Food 2019, 17, 509-516. [CrossRef] 
9. López-Prieto, A.; Rodríguez-López, L.; Rincón-Fontán, M.; Cruz, J.M.; Moldes, A.B. Characterization of Extracellular and Cell Bound Biosurfactants Produced by Aneurinibacillus Aneurinilyticus Isolated from Commercial Corn Steep Liquor. Microbiol. Res. 2021, 242, 126614. [CrossRef]

10. Marchant, R.; Banat, I.M. Biosurfactants: A Sustainable Replacement for Chemical Surfactants? Biotechnol. Lett. 2012, 34, 1597-1605. [CrossRef]

11. Marchant, R.; Banat, I.M. Microbial Biosurfactants: Challenges and Opportunities for Future Exploitation. Trends Biotechnol. 2012, 30, 558-565. [CrossRef]

12. Santos, D.K.F.; Rufino, R.D.; Luna, J.M.; Santos, V.A.; Sarubbo, L.A. Biosurfactants: Multifunctional Biomolecules of the 21st Century. Int. J. Mol. Sci. 2016, 17, 401. [CrossRef]

13. Jimoh, A.A.; Lin, J. Biosurfactant: A New Frontier for Greener Technology and Environmental Sustainability. Ecotoxicol. Environ. Saf. 2019, 184, 109607. [CrossRef]

14. Desai, J.D.; Banat, I.M. Microbial Production of Surfactants and Their Commercial Potential. Microbiol. Mol. Biol. Rev. 1997, 61, 47-64. [CrossRef]

15. Dubey, K.V.; Juwarkar, A.A.; Singh, S.K. Adsorption-Desorption Process Using Wood-Based Activated Carbon for Recovery of Biosurfactant from Fermented Distillery Wastewater. Biotechnol. Prog. 2005, 21, 860-867. [CrossRef] [PubMed]

16. Liu, T.; Montastruc, L.; Gancel, F.; Zhao, L.; Nikov, I. Integrated Process for Production of Surfactin. Part 1: Adsorption Rate of Pure Surfactin onto Activated Carbon. Biochem. Eng. J. 2007, 35, 333-340. [CrossRef]

17. Montastruc, L.; Liu, T.; Gancel, F.; Zhao, L.; Nikov, I. Integrated Process for Production of Surfactin. Part 2. Equilibrium and Kinetic Study of Surfactin Adsorption onto Activated Carbon. Biochem. Eng. J. 2008, 38, 349-354. [CrossRef]

18. Carmen dos Santos Mendes de Oliveira, A.; da Silva Bezerra, M.; de Araujo Padilha, C.E.; Melchuna, A.M.; de Macedo, G.R.; dos Santos, E.S. Recovery of Rhamnolipids Produced by Pseudomonas Aeruginosa Using Acidic Precipitation, Extraction, and Adsorption on Activated Carbon. Sep. Sci. Technol. 2013, 48, 2852-2859. [CrossRef]

19. Chen, H.L.; Lee, Y.S.; Wei, Y.H.; Juang, R.S. Purification of Surfactin in Pretreated Fermentation Broths by Adsorptive Removal of Impurities. Biochem. Eng. J. 2008, 40, 452-459. [CrossRef]

20. Jauregi, P.; Kourmentza, K. Membrane filtration of biosurfactants. In Separation of Functional Molecules in Food by Membrane Technology; Elsevier Inc.: Amsterdam, The Netherlands, 2019; pp. 79-112. ISBN 9780128150566.

21. Díaz De Rienzo, M.A.; Kamalanathan, I.D.; Martin, P.J. Comparative Study of the Production of Rhamnolipid Biosurfactants by B. Thailandensis E264 and P. Aeruginosa ATCC 9027 Using Foam Fractionation. Process. Biochem. 2016, 51, 820-827. [CrossRef]

22. Najmi, Z.; Ebrahimipour, G.; Franzetti, A.; Banat, I.M. In Situ Downstream Strategies for Cost-Effective Bio/Surfactant Recovery. Biotechnol. Appl. Biochem. 2018, 65, 523-532. [CrossRef]

23. Juang, R.S.; Chen, H.L.; Chen, Y.S. Membrane Fouling and Resistance Analysis in Dead-End Ultrafiltration of Bacillus Subtilis Fermentation Broths. Sep. Purif. Technol. 2008, 63, 531-538. [CrossRef]

24. Chen, H.L.; Chen, Y.S.; Juang, R.S. Flux Decline and Membrane Cleaning in Cross-Flow Ultrafiltration of Treated Fermentation Broths for Surfactin Recovery. Sep. Purif. Technol. 2008, 62, 47-55. [CrossRef]

25. De Andrade, C.J.; de Andrade, L.M.; Rocco, S.A.; Sforça, M.L.; Pastore, G.M.; Jauregi, P. A Novel Approach for the Production and Purification of Mannosylerythritol Lipids (MEL) by Pseudozyma Tsukubaensis Using Cassava Wastewater as Substrate. Sep. Purif. Technol. 2017, 180, 157-167. [CrossRef]

26. Vicente, R.; de Andrade, C.J.; de Oliveira, D.; Ambrosi, A. A Prospection on Membrane-Based Strategies for Downstream Processing of Surfactin. Chem. Eng. J. 2021, 415, 1-9. [CrossRef]

27. Dalheim, M.; Omtvedt, L.A.; Bjørge, I.M.; Akbarzadeh, A.; Mano, J.F.; Aachmann, F.L.; Strand, B.L. Mechanical Properties of Ca-Saturated Hydrogels with Functionalized Alginate. Gels 2019, 5, 23. [CrossRef] [PubMed]

28. Aburabie, J.H.; Puspasari, T.; Peinemann, K.V. Alginate-Based Membranes: Paving the Way for Green Organic Solvent Nanofiltration. J. Memb. Sci. 2020, 596, 117615. [CrossRef]

29. Moldes, A.B.; Vázquez, M.; Domínguez, J.M.; Díaz-Fierros, F.; Barral, M.T. Evaluation of Mesophilic Biodegraded Grape Marc as Soil Fertilizer. Appl. Biochem. Biotechnol. 2007, 141, 27-36. [CrossRef] [PubMed]

30. Perez-Ameneiro, M.; Vecino, X.; Barbosa-Pereira, L.; Cruz, J.M.; Moldes, A.B. Removal of Pigments from Aqueous Solution by a Calcium Alginate-Grape Marc Biopolymer: A Kinetic Study. Carbohydr. Polym. 2014, 101, 954-960. [CrossRef]

31. Perez-Ameneiro, M.; Vecino, X.; Cruz, J.M.; Moldes, A.B. Wastewater Treatment Enhancement by Applying a Lipopeptide Biosurfactant to a Lignocellulosic Biocomposite. Carbohydr. Polym. 2015, 131, 186-196. [CrossRef]

32. Hull, S.R.; Montgomery, R. Myo-Inositol Phosphates in Corn Steep Water. J. Agric. Food Chem. 1995, 43, 1516-1523. [CrossRef]

33. Hull, S.R.; Yang, B.Y.; Venzke, D.; Kulhavy, K.; Montgomery, R. Composition of Corn Steep Water during Steeping. J. Agric. Food Chem. 1996, 44, 1857-1863. [CrossRef]

34. Moldes, A.B.; Cruz, J.M.; Devesa, R.; Vecino, X. Method for Separating the Surfactants Present in the Washing Liquors of Corn, and Uses. Patent WO2014044876A1, 27 March 2014.

35. Perez-Ameneiro, M.; Vecino, X.; Cruz, J.M.; Moldes, A.B. Physicochemical Study of a Bio-Based Adsorbent Made from Grape Marc. Ecol. Eng. 2015, 84, 190-193. [CrossRef]

36. Perez-Ameneiro, M.; Vecino, X.; Vega, L.; Devesa-Rey, R.; Cruz, J.M.; Moldes, A.B. Elimination of Micronutrients from Winery Wastewater Using Entrapped Grape Marc in Alginate Beads. CYTA-J. Food 2014, 12, 73-79. [CrossRef] 
37. Bustos, G.; Calvar, S.; Vecino, X.; Cruz, J.M.; Moldes, A.B. Industrial Symbiosis Between the Winery and Environmental Industry Through the Utilization of Grape Marc for Water Desalination Containing Copper ( II ). Water Air Soil Pollut. 2018, 229, 1-11. [CrossRef]

38. Ndiaye, B.; Bustos, G.; Calvar, S.; Vecino, X.; Cruz, J.M.; Moldes, A.B.; Pérez-Cid, B. Selective Adsorption Capacity of Grape Marc Hydrogel for Adsorption of Binary Mixtures of Dyes. Water Air Soil Pollut. 2020, 231, 1-14. [CrossRef]

39. Pérez-Cid, B.; Calvar, S.; Moldes, A.B.; Manuel Cruz, J. Effective Removal of Cyanide and Heavy Metals from an Industrial Electroplating Stream Using Calcium Alginate Hydrogels. Molecules 2020, 25, 5183. [CrossRef]

40. Moldes, A.; Vecino, X.; Rodrí́guez-López, L.; Rincón-Fontán, M.; Cruz, J.M. Biosurfactants: The use of biomolecules in cosmetics and detergents. In New and Future Developments in Microbial Biotechnology and Bioengineering; Rodrigues, A.G., Ed.; Elsevier: Amsterdam, The Netherlands, 2020; pp. 163-185. ISBN 9780444643018.

41. Vecino, X.; Barbosa-Pereira, L.; Devesa-Rey, R.; Cruz, J.M.; Moldes, A.B. Optimization of Extraction Conditions and Fatty Acid Characterization of Lactobacillus Pentosus Cell-Bound Biosurfactant/Bioemulsifier. J. Sci. Food Agric. 2015, 95, 313-320. [CrossRef] [PubMed]

42. Andrade, R.F.S.; Silva, T.A.L.; Ribeaux, D.R.; Rodriguez, D.M.; Souza, A.F.; Lima, M.A.B.; Lima, R.A.; Alves Da Silva, C.A.; Campos-Takaki, G.M. Promising Biosurfactant Produced by Cunninghamella Echinulata UCP 1299 Using Renewable Resources and Its Application in Cotton Fabric Cleaning Process. Adv. Mater. Sci. Eng. 2018, 2018, 1-12. [CrossRef]

43. Rodríguez-López, L.; Rincón-Fontán, M.; Vecino, X.; Cruz, J.M.; Moldes, A.B. Extraction, Separation and Characterization of Lipopeptides and Phospholipids from Corn Steep Water. Sep. Purif. Technol. 2020, 248, 117076. [CrossRef]

44. Li, J.; Deng, M.; Wang, Y.; Chen, W. Production and Characteristics of Biosurfactant Produced by Bacillus Pseudomycoides BS6 Utilizing Soybean Oil Waste. Int. Biodeterior. Biodegrad. 2016, 112, 72-79. [CrossRef]

45. Ma, Y.; Kong, Q.; Qin, C.; Chen, Y.; Chen, Y.; Lv, R.; Zhou, G. Identification of Lipopeptides in Bacillus Megaterium by Two-Step Ultrafiltration and LC-ESI-MS/MS. AMB Express 2016, 6, 1-15. [CrossRef]

46. LeClere, S.; Schmelz, E.A.; Chourey, P.S. Phenolic Compounds Accumulate Specifically in Maternally-Derived Tissues of Developing Maize Kernels. Cereal Chem. 2007, 84, 350-356. [CrossRef]

47. Rodríguez-López, L.; Vecino, X.; Barbosa-Pereira, L.; Moldes, A.B.; Cruz, J.M. A Multifunctional Extract from Corn Steep Liquor: Antioxidant and Surfactant Activities. Food Funct. 2016, 7, 3724-3732. [CrossRef] [PubMed]

48. Chen, Y.; Liu, S.A.; Mou, H.; Ma, Y.; Li, M.; Hu, X. Characterization of Lipopeptide Biosurfactants Produced by Bacillus Licheniformis MB01 from Marine Sediments. Front. Microbiol. 2017, 8, 1-11. [CrossRef] [PubMed]

49. Béchet, M.; Caradec, T.; Hussein, W.; Abderrahmani, A.; Chollet, M.; Leclére, V.; Dubois, T.; Lereclus, D.; Pupin, M.; Jacques, P. Structure, Biosynthesis, and Properties of Kurstakins, Nonribosomal Lipopeptides from Bacillus spp. Appl. Microbiol. Biotechnol. 2012, 95, 593-600. [CrossRef] [PubMed]

50. Hathout, Y.; Ho, Y.P.; Ryzhov, V.; Demirev, P.; Fenselau, C. Kurstakins: A New Class of Lipopeptides Isolated from Bacillus Thuringiensis. J. Nat. Prod. 2000, 63, 1492-1496. [CrossRef] 